\title{
MYCOPLASMACIN : MYCOPLASMA GROWTH INHIBITORY SUBSTANCE PRODUCED BY MYCOPLASMAS
}

\author{
MASAHIRO NAKAMURA, TOHRU ITOH AND NAOKO HIRATA \\ Department of Microbiology, Kurume University School of Medicine, \\ Kurume, 830, Japan
}

(Received for publication December 10, 1975)

\begin{abstract}
A phenomenon that the growth of mycoplasma is inhibited by chloroform-inactivated mycoplasmas was described. The characteristics of the substance is not clear yet, but there is a possible method for subclassification of mycoplasmas which are classified by other routine methods, for instance antiserum growth inhibition, polyacrylamide gel diffusion, and so on.
\end{abstract}

Mycoplasmas are the smallest microorganisms which can grow on cell-free medium. A few years ago, two viruses were isolated from the strains of Acholeplasma laidlawii ${ }^{31}{ }^{4)}$. In addition, a report concerning mycoplasma-associated induction of interferon in ovine leukocytes ${ }^{5)}$ was recently appeared. Furthermore, two strains of thermophilic, acidophilic, Thermoplasma acidophilum 2) were isolated from a coal refuse pile at the Friar Tuck mine in southwestern Indiana, U. S. A., and their characteristics have been intensively studied. These accumulating data have been expanding and characterizing the concept regarding mycoplasmas whose knowledges had been obtained since the success of their cultivation on cell-free culture medium. Recently, we found a substance produced by mycoplasma, capable of killing cells of related mycoplasma strains. We propose to call this substance mycoplasmacin. The purpose of this paper is to add further one character to the properties of mycoplasmas which have been already widely known.

In this report, a total of 12 prototype human and animal strains which have been maintained in our laboratory were studied for production of mycoplasmacin, and also employed as indicators susceptible to mycoplasmacin.

\section{MATERIALS AND METHODS}

\section{Mycoplasmas}

Mycoplasma pneumoniae $\mathrm{FH}$ strain, Mycoplasma fermentans-C ATCC, Mycoplasma hominis 1-C ATCC, Mycoplasma salivarium-C Hup 127, Mycoplasma orale N-1 strain were kindly supplied by Dr. Hayflick, Mycoplasma pneumoniae Mac strain by Keio University, and $\mathrm{Myco-}$ plasma orale 1 ATCC 15539 , orale 2, Mycoplasma arthritidis PG-6, PG-27, 16T, and 07 strains by Tokyo University.

\section{Procedure}

The "Streak-plate" method" on PPLO 
agar was used for demonstrating mycoplasmacin. After a test mycoplasma was grown as a streak for 5 or 9 days at $37^{\circ} \mathrm{C}$ on the PPLO agar, the growth was killed with chloroform vapor for $15 \mathrm{~min}$ and then indicator strains were inoculated as parallel lines at right angles to the position of the original inoculum. Two or three strains were usually inoculated as indicators per plate $(65 \mathrm{~mm})$. Reading of the results was performed after 5 or 9 days of incubation at $37^{\circ} \mathrm{C}$. Mycoplasmacin activities were represented by the presence of inhibitory zone microscopically observed (Fig. 1).

\section{RESULTS AND DISCUSSION}

In Table 1, it is demonstrated that there were 8 of 12 strains tested which produce the active mycoplasmacidal component. The widest spectrum was found in Mycoplasma salivarium and no bacteriocins were recognized in Mycoplasma

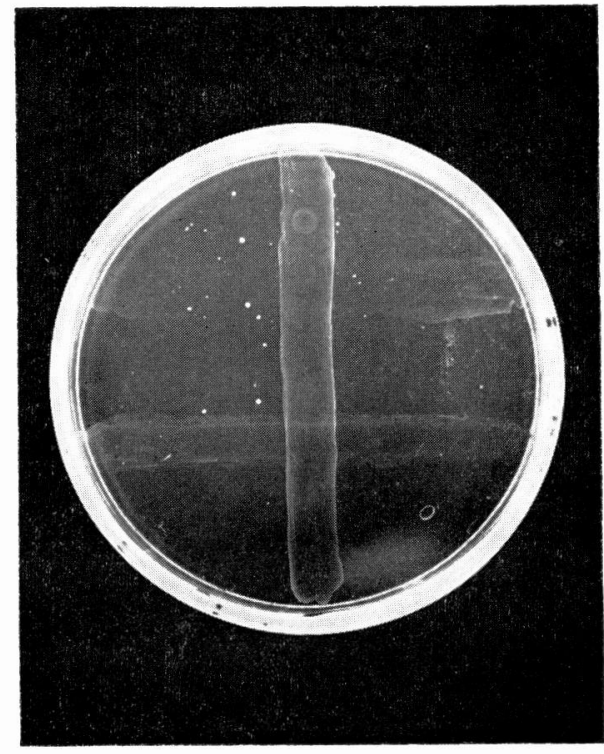

Fig. 1 Inhibitory pattern of Mycoplasmacin Mycoplasma arthritidis, PG 27. Indicators strains: upper is Mycoplasma arthritidis, PG 27 strain and lower is Mycoplasma pneumoniae Mac strain.

TABLE 1

Mycoplasmacin patterns

\begin{tabular}{|c|c|c|c|c|c|c|c|c|c|c|c|c|}
\hline \multirow{3}{*}{$\begin{array}{l}\text { Mycoplasmacin } \\
\text { producing } \\
\text { strains }\end{array}$} & \multicolumn{12}{|c|}{ Indicator } \\
\hline & \multicolumn{2}{|c|}{$\begin{array}{l}\text { M.pneu- } \\
\text { moniae }\end{array}$} & \multirow{2}{*}{$\begin{array}{l}\text { M.fer- } \\
\text { mentans }\end{array}$} & \multirow{2}{*}{$\begin{array}{l}\text { M. homi- } \\
\text { nis }\end{array}$} & \multirow{2}{*}{$\begin{array}{l}\text { M.sali- } \\
\text { varium }\end{array}$} & \multicolumn{3}{|c|}{ M. orale } & \multicolumn{4}{|c|}{ M.arthritidis } \\
\hline & $\mathrm{Mac}$ & $\mathrm{FH}$ & & & & 1 & 2 & $N-1$ & PG6 & $\mathrm{PG} 27$ & $16 \mathrm{~T}$ & 07 \\
\hline M.pneumoniae Mac & $-*$ & - & - & - & - & - & - & - & - & - & - & - \\
\hline $\mathrm{FH}$ & - & - & - & - & - & - & - & - & - & - & - & + \\
\hline M.fermentans & - & - & - & - & - & - & - & - & - & - & - & - \\
\hline M. hominis & - & - & - & - & - & - & - & - & - & - & - & - \\
\hline M. salivarium & - & H & - & H & H & - & H & H & - & H & H & H \\
\hline \multirow[t]{2}{*}{ M.orale } & - & - & - & - & - & + & - & $H$ & - & - & - & $H$ \\
\hline & - & - & - & - & + & - & - & - & - & $H$ & - & H \\
\hline $\mathrm{N}-1$ & - & - & - & - & + & H & - & $H$ & - & - & - & - \\
\hline \multicolumn{13}{|l|}{ M.arthritidis } \\
\hline P G -6 & - & - & + & - & + & - & - & - & + & H & HH & H \\
\hline $\mathrm{P} \mathrm{G}-27$ & - & H & - & - & - & - & H & - & + & t+ & HI & H \\
\hline $16 \mathrm{~T}$ & $H$ & - & - & - & + & - & H & - & - & + & $H$ & HI \\
\hline 07 & + & + & - & - & + & - & + & - & - & + & + & H \\
\hline
\end{tabular}

* - : No inhibiton, + : Inhibitory zone, $3-5 \mathrm{~mm},+$ : 6-8 $\mathrm{mm}$, $\#:>9 \mathrm{~mm}$. 
pneumoniae Mac strain, Mycoplasma fermentans, and Mycoplasma hominis.

The results indicated here are just preliminary. The characteristics of mycoplasmacin, and the possibility for classification of mycoplasmas will be reported in the near future. The problems concerning selection of indicator strain for mycoplasmacin are insoluble.

However, this is the first description indicating the evidence of inhibitory action present in mycoplasma.

\section{REFERENCES}

1) Аввотт, J.D. and Shannon, R.: A method of typing Shigella sonnei using colicin production as a marker. J. Clin. Pathol, 11, 71-77, 1958.

2) Darland, G., Brock, T.D., Samsonoff, W. and Conti, S. F.: A thermophilic, acidophilic mycoplasma isolated from a coal refuse pile. Science, 170, 1416-1418, 1970.

3 ) Gourlay, R. N. : Isolation of a virus infecting a strain of Mycoplasma laidlawii. Nature, 225, 1165, 1970.

4 ) Gourlay, R. N. Bruce, J. and Garwes, D. J.: Characterization of mycoplasmatales virus laidlawii 1. Nature New Biol, 229, 118-119, 1971.

5 ) Rinaldo, C.R.Jr, Overall, J.C. Jr., Cole, B.C. and GLASGOw,L.A.: Mycoplasmaassociated induction of interferon in ovine leukocytes. Infect. Immun. 8, 796-803, 1973. 